\title{
Proteomics analysis of the response of the marine bacterium Marinobacter adhaerens HP15 to the diatom Thalassiosira weissflogii
}

\author{
Antje Stahl, Matthias S. Ullrich* \\ Department of Life Sciences and Chemistry, Jacobs University Bremen, 28759 Bremen, Germany
}

\begin{abstract}
Bacteria are often associated with diatoms through attachment or by being in close proximity. Certain bacteria-diatom interactions are assumed to be mutualistic. Substrates determining these interactions have been identified, yet in-depth studies on bacteria-diatom interactions remain scarce. In the present study, we applied a proteomics approach to obtain a deeper perspective of the response of a bacterium to a diatom. A bilateral model system was used, comprising the marine $\gamma$ proteobacterium Marinobacter adhaerens HP15 and the diatom Thalassiosira weissflogii. In co-cultivation experiments, the interacting partners were physically separated by dialysis tubing allowing diffusion of compounds. The proteome of $M$. adhaerens HP15 derived from cell lysates was sampled and compared with protein samples from diatomfree bacterial cultures. Proteome alterations were visualized by 2-dimensional gel electrophoresis, and differentially expressed proteins were analyzed by mass spectrometry. We hypothesized that observable protein alterations will give information on substrates that determine a potential mutualistic interaction. Our results suggested a differentiated nutrient supply for $M$. adhaerens HP15 during cocultivation. The bacterium seemed to benefit from the release of amino acids by the diatom, as indicated by an up-regulation of several transporter elements responsible for amino acid uptake. To substantiate these results, a screening for suitable nutrient substrates of $M$. adhaerens was conducted revealing that amino acids appeared to be the preferred carbon source of the bacterium, while various tested sugars were not utilized.
\end{abstract}

${ }^{*}$ Corresponding author: m.ullrich@jacobs-university.de

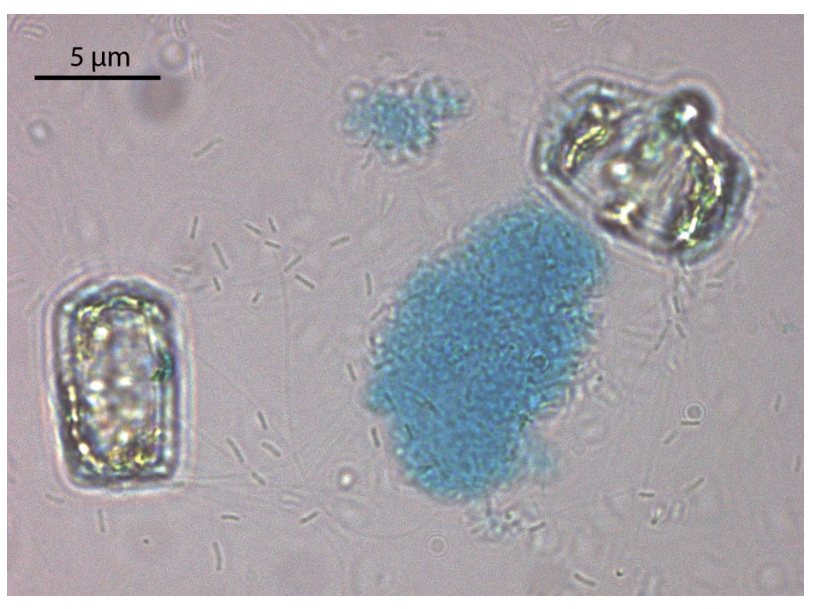

Diatom cells (large) releasing Alcian blue-stained transparent exopolymeric particles (blue) and surrounded by Marinobacter adhaerens cells (rod-shaped).

Photo: Veronika Will

KEY WORDS: Bacteria-diatom interaction - Mutualism - Marinobacter adhaerens HP15 - Thalassiosira weissflogii - Carbon cycle · Transparent exopolymer particles

\section{INTRODUCTION}

Despite their small size and inconspicuous appearance, diatoms contribute about one-fifth of global primary production (Field et al. 1998). They do not only fix atmospheric carbon dioxide but also provide carbon and other nutrients to their surroundings due to

() The authors 2016. Open Access under Creative Commons by Attribution Licence. Use, distribution and reproduction are unrestricted. Authors and original publication must be credited. 
the release of exudates that may coagulate and form transparent exopolymer particles (TEPs) (Passow 2000, Passow et al. 2001). Depending on certain environmental parameters such as nutrient availability, up to $50 \%$ of carbon fixed during primary production may be re-allocated in the form of exudates (Beauvais et al. 2006). Formed TEPs serve as valuable nutrient and carbon sources for other microbes, thus fueling the degradation and re-allocation of compounds in the upper water column on a micro-scale level (Azam \& Malfatti 2007). Indeed, algal bloom dynamics are closely coupled to bacterial dynamics: depending on the succession of a bloom, different bacterial taxa specialized in degradation of specific substrates may peak in abundance (Fandino et al. 2005, RooneyVarga et al. 2005, Mayali et al. 2011, Teeling et al. 2012). Therefore, primary production of diatoms and subsequent interactions between both bacteria and diatoms are important in carbon and nutrient cycling on a global scale (Azam et al. 1994).

Diatoms and other single-celled algae such as dinoflagellates are usually colonized by bacteria in their phycosphere (Baker \& Kemp 2014, Sison-Mangus et al. 2014). The phycosphere is defined as the direct surrounding of a micro-alga, in which bacterial growth is impacted due to the release of algal compounds (Bell \& Mitchell 1972). Within this area, bacteria may be attached to the cell surface or found swarming in close proximity (Blackburn et al. 1998). Different diatom genera or even species harbor distinct groups of bacteria (Grossart et al. 2005, Guannel et al. 2011, Eigemann et al. 2013, Sison-Mangus et al. 2014), leading to the assumption that bacterial colonization is diatom species-specific. Individual algal exudates may selectively attract particular bacterial species (Seymour et al. 2009). An intimate co-evolution of diatoms and colonizing bacteria has been suggested, based on the finding that several hundred genes in the diatom Phaeodactylum tricornutum are of bacterial origin (Bowler et al. 2008). Although parasitic or commensalistic relationships have been observed (Bratbak \& Thingstad 1985, Paul \& Pohnert 2011), synergistic relationships are common, in which both partners profit from the presence of the other (Grossart 1999). A number of benefits are known for bacteria and diatoms or other singlecelled algae that are gained by both partners during the interaction (Amin et al. 2012). Past studies have focused on e.g. TEP production dynamics, release of hydrolytic enzymes, or growth behavior (Grossart 1999, Gärdes et al. 2012). However, in-depth studies that use advanced metabolomics, molecular genetics, or proteomics approaches remain scarce.
A major benefit for bacteria is the availability of metabolites such as TEPs (Grossart 1999), which are mainly composed of carbohydrate polymers and to a lesser content of nutrient sources such as proteins, peptides, amino acids, or lipids (Myklestad et al. 1989, Myklestad 1995, Biddanda \& Benner 1997). Bacteria do not only metabolize but also may alter TEP formation and release, resulting in increase or decrease of TEP production (Bruckner et al. 2011, Gärdes et al. 2012). Because TEPs may serve as a stickiness-increasing 'glue' and therefore trigger particle formation and sinking, bacteria-diatom interactions impact the biological carbon pump (Alldredge \& Gotschalk 1989, Ducklow et al. 2001).

Diatoms are assumed to benefit from synergistic bacterial interactions due to the production of vitamins by bacteria, with cobalamin (vitamin $\mathrm{B}_{12}$ ) being the most often discussed candidate in this context (Droop 1970, Cole 1982, Croft et al. 2005). A wide range of algae are auxotrophic for cobalamin (Croft et al. 2005), whereas auxotrophy towards other vitamins such as thiamine (vitamin $\mathrm{B}_{1}$ ) or biotin (vitamin $\mathrm{B}_{7}$ ) is less widespread but is also a potential trigger for synergistic relationships (Croft et al. 2006, WagnerDöbler et al. 2010). Another valuable 'traded item' between bacteria and diatoms is iron. Iron is a limiting growth factor for phytoplankton in certain parts of the ocean (Behrenfeld et al. 1996) and could be provided by algae-associated bacteria via their ability to form siderophores (Amin et al. 2009). Nitrogen is a further 'traded item' provided by bacteria, as shown for cyanobacteria (Foster et al. 2011) or for a Sulfitobacter strain (Amin et al. 2015). The latter bacterium did not only provide ammonia, but also produced the plant hormone indole-3-acetic acid (IAA), thus generating a growth-promoting effect in its co-cultivated diatom partner Pseudo-nitzschia multiseries (Amin et al. 2015). Bruckner et al. (2011) applied a proteomics approach to an in vitro co-cultivation of the diatom $P$. tricornutum and Escherichia coli K12. These authors studied diatom growth behavior, TEP formation, and amino acid release and further focused on the extracellular proteome. They found bacterial extracellular proteins induced during co-cultivation that were associated with proteinbinding, transport, biofilm formation, and carbohydrate turnover. In a co-cultivation experiment of Thalassiosira pseudonana and a member of the Roseobacter clade, Dinoroseobacter shibae, Paul et al. (2013) used metabolomic techniques for the analysis of intracellular diatom metabolites. They observed an increase in amino acid concentration in $T$. pseudonana during co-cultivation. Additionally, long- 
chain fatty acids and undefined carbohydrates were increased in the diatom in the presence of bacteria.

The aim of the present study was to contribute to an in-depth understanding of bacteria-diatom interactions by focusing on the response of a bacterium to a diatom. A proteomics approach was applied to a model interaction system comprising the diatom $T$. weissflogii and the marine bacterium Marinobacter adhaerens HP15. This model system had been established in the past in order to investigate bacterial colonization of diatoms and formation of marine aggregates (Sonnenschein et al. 2011). It has since successfully served in a set of studies dissecting this interaction (Gärdes et al. 2011, 2012, Sonnenschein et al. 2012). For the current proteomics approach, an interaction was chosen whereby both partners were physically separated but could exchange signal molecules and other chemical compounds. Bacterial proteins were thus identified, that were altered in expression due to the exchange of such compounds. The focus was set on cytoplasmic proteins, taking advantage of their hydrophilic character that makes them suitable for the applied methodical approaches. We further assumed that most proteomic changes in response to the interaction would be recognizable within the cytoplasmic proteome. The potential role of altered expression of proteins during the interaction was experimentally supported by a screening for carbon sources that the bacterium is able to metabolize.

\section{MATERIALS AND METHODS}

\section{Culture conditions for Marinobacter adhaerens HP15 and Thalassiosira weissflogii}

M. adhaerens HP15 (Grossart et al. 2004, Kaeppel et al. 2012) was cultured in $500 \mathrm{ml}$ Erlenmeyer flasks in liquid marine broth (MB) medium (Sonnenschein et al. 2011) at $18^{\circ} \mathrm{C}$ under constant shaking at $250 \mathrm{rpm}$. Axenic $T$. weissflogii diatom cultures (CCMP 1336; received from the Provasoli-Guillard National Center for Culture of Marine Phytoplankton) were grown in $2000 \mathrm{ml}$ Erlenmeyer flasks in $\mathrm{f} / 2$ medium prepared from filtered and autoclaved North Sea water $\left(\mathrm{NSW} ; 15^{\circ} \mathrm{C}, 12: 12 \mathrm{~h}\right.$ light:dark period at $150 \mu \mathrm{m}$ photons $\mathrm{m}^{-2} \mathrm{~s}^{-1}$ ). In detail, $\mathrm{f} / 2$ medium was supplemented with $8.82 \times 10^{-4} \mathrm{M}$ $\mathrm{NaNO}_{3}, 3.62 \times 10^{-5} \mathrm{M} \mathrm{NaH}_{2} \mathrm{PO}_{4} \cdot 2 \mathrm{H}_{2} \mathrm{O}, 1.06 \times 10^{-4} \mathrm{M}$ $\mathrm{Na}_{2} \mathrm{SiO}_{3} \cdot 9 \mathrm{H}_{2} \mathrm{O}, 1 \mathrm{ml} \mathrm{l}^{-1}$ trace element and vitamin solution according to Guillard (1975). The cultures' axenity was constantly checked by light microscopy and plating of culture aliquots on $\mathrm{MB}$ and LuriaBertani agar medium. Bacterial cell numbers during the experiment were determined by serial dilution plating in triplicate, and diatom numbers were determined with a Sedgwick-Rafter counting chamber, using a Zeiss Axiostar plus microscope (Carl Zeiss) at 100× magnification.

\section{Co-cultivation of M. adhaerens HP15 with $T$. weissflogii}

M. adhaerens HP15 cells were harvested from liquid culture in exponential growth phase $\left(\mathrm{OD}_{600}\right.$ $0.5-1.0)$ by centrifugation $\left(3000 \times g, 15 \mathrm{~min}\right.$ at $\left.4^{\circ} \mathrm{C}\right)$. Cells were washed twice in $75 \%(\mathrm{v} / \mathrm{v}) \mathrm{NSW}$, suspended, and starved for $3 \mathrm{~h}$ in $75 \% \mathrm{NSW}$ at $18^{\circ} \mathrm{C}$ under constant shaking $(250 \mathrm{rpm})$. Cells were then pelleted and suspended in $75 \%$ NSW supplemented with $3.4 \times 10^{-2} \mathrm{M}$ glutamate as the sole carbon and nitrogen source and $2.12 \times 10^{-3} \mathrm{M}$ phosphate $(\mathrm{Na}$ $\mathrm{H}_{2} \mathrm{PO}_{4} \cdot 2 \mathrm{H}_{2} \mathrm{O}$ ). The phosphate content was chosen according to the nitrogen molarity provided by glutamate and the resulting favorable Redfield ratio of 16:1 N:P (Hecky et al. 1993). The initial start $\mathrm{OD}_{600}$ for the bacterial culture was adjusted to $0.05\left(\sim 7 \times 10^{6}\right.$ cells $\mathrm{ml}^{-1}$ ).

Three individually grown $T$. weissflogii pre-cultures in equal growth state (TW I-III) were split into 2 parts (Fig. 1). Half of each culture was used for sampling of the culture supernatant. For this, cultures were centrifuged under mild conditions $\left(1250 \times g, 10 \mathrm{~min}\right.$ at $\left.4^{\circ} \mathrm{C}\right)$ to avoid cell lysis, and the supernatant was filtered through $0.2 \mu \mathrm{m}$ pore size filters (hydrophilic). The second half was used for direct co-cultivation of $T$. weissflogii with the bacterium.

Two treatments were chosen, in which $M$. adhaerens HP15 was cultivated either with the supernatant of the diatom culture, serving as a reference for the 2-dimensional protein gel analysis (REF I-III) or was co-cultivated with the diatom culture itself, serving as the actual treatment (TRE I-III, Fig. 1). The reference was prepared with diatom supernatant in order to (1) normalize effects of differential nutrient status that create artifacts in the proteome (as observed in pilot experiments conducted without diatom culture supernatant) and (2) to identify those proteomic shifts in the treatment that exclusively appear due to the active response of the diatom to the bacterium. For these cultivations, 100 $\mathrm{ml}$ of diatom culture supernatant or diatom culture, respectively, were loaded into flexible dialysis tubing 


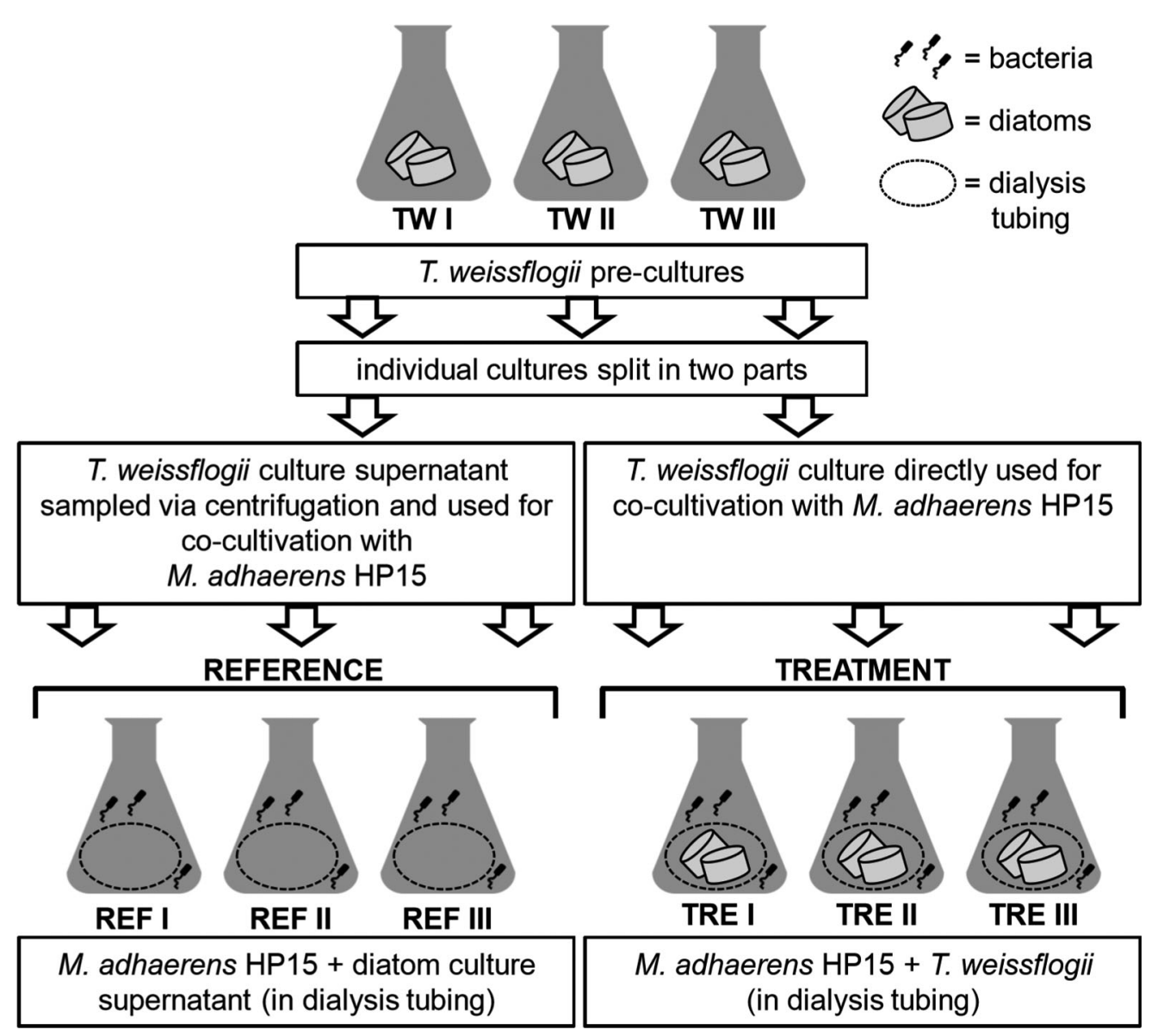

Fig. 1. Experimental set-up of the co-cultivation experiment. Three individual pre-cultures of Thalassiosira weissflogii were cultivated (TW I-III). Each culture was split in 2 parts: one was used for sampling of the culture supernatant by centrifugal removal of the diatom cells; the other was directly used for co-cultivation. Both culture supernatant ('reference') and direct diatom culture ('treatment') were loaded into flexible dialysis tubing and combined with a Marinobacter adhaerens HP15 culture. $M$. adhaerens HP15 was previously prepared in f/2 medium supplemented with $3.4 \times 10^{-2} \mathrm{M}_{\text {glutamate }}\left(\mathrm{OD}_{600}=0.05\right)$. Both references and treatments were conducted in triplicate (REF I-III; TRE I-III). Cultures were gently stirred during incubation to support diffusion of compounds through the dialysis tubing

(25 mm ZelluTrans hose, molecular weight cut-off 12 000-14 000; Carl Roth). Filled tubes were placed into a $200 \mathrm{ml}$ suspension of $M$. adhaerens HP15 cells, prepared in a $1000 \mathrm{ml}$ Erlenmeyer flask. M. adhaerens HP15 cells had previously been starved, pelleted, and suspended in corresponding medium to an $\mathrm{OD}_{600}$ of 0.05 . All treatments were further supplemented with trace elements, vitamins, and nutrients, as done for $\mathrm{f} / 2$ medium. Treatments were carried out in triplicate. Culture conditions used were those applied for diatom cultivation $\left(15^{\circ} \mathrm{C} ; 12: 12 \mathrm{~h}\right.$ light:dark period at $150 \mu \mathrm{m}$ photons $\mathrm{m}^{-2} \mathrm{~s}^{-1}$ ). Cultures were gently stirred (50 mm magnetic stirring bar, $60 \mathrm{rpm}$ ) to guarantee diffusion of chemical signal molecules through the dialysis tubing.
Protein sampling, 2-dimensional sodium dodecyl sulfate polyacrylamide gel electrophoresis (2D-SDS-PAGE), and data analysis

Bacterial cells were harvested after $66.5 \mathrm{~h}$ of cocultivation, marking the late exponential phase, from $200 \mathrm{ml}$ of culture by centrifugation at $3000 \times g$. The cell pellet was suspended in chilled sonication buffer (100 mM Tris- $\mathrm{HCl}, \mathrm{pH}$ 7.5; $50 \mathrm{mM} \mathrm{NaCl} ; 0.5 \mathrm{mM}$ dithiothreitol [DTT]; Protease Inhibitor Cocktail according to the manufacturer's instructions [Thermo Scientific]). Cell suspensions were sonicated on ice $(10 \times 1$ s, 4 s break, 3 repeats; amplitude $70 \%$; Active Motif ${ }^{\circledR}$ sonicator), and cell debris was centrifuged off afterwards $\left(16100 \times g, 30 \mathrm{~min}\right.$ at $\left.4^{\circ} \mathrm{C}\right)$. Supernatants 
were immediately used or kept at $-80^{\circ} \mathrm{C}$. Protein content of the supernatant was determined via a bicinchoninic acid test according to the manufacturer's instructions (Thermo Scientific).

To conduct isoelectric focusing, $80 \mu \mathrm{g}$ of protein were applied to immobilized $\mathrm{pH}$ gradient (IPG) strips

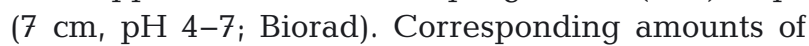
protein were precipitated and cleaned via acetone precipitation. In detail, 1 volume of protein suspension was mixed with 4 volumes of ice-cold acetone $\left(-20^{\circ} \mathrm{C}\right)$. Samples were kept at $-20^{\circ} \mathrm{C}$ for at least $3 \mathrm{~h}$. A protein pellet was harvested afterwards by centrifugation $\left(16100 \times g, 30 \mathrm{~min}\right.$ at $\left.4^{\circ} \mathrm{C}\right)$. The supernatant was decanted and the protein pellet briefly air-dried. The pellet was suspended in rehydration buffer $(2 \mathrm{M}$ thiourea, $6 \mathrm{M}$ urea, $16.2 \times 10^{-3} \mathrm{M}$ CHAPS, $25.9 \times$ $10^{-3} \mathrm{M}$ DTT) and supplemented with ampholytes according to the manufacturer's specifications (Biorad). IPG-strips were soaked with protein suspension for $\sim 14 \mathrm{~h}$. Isoelectric focusing was carried out on a Biorad Protean ${ }^{\circledR}$ i12 ${ }^{\text {TM }}$ IEF Cell $(50 \mathrm{~V}, 70 \mathrm{~min} ; 150 \mathrm{~V}$, $20 \mathrm{~min} 300 \mathrm{~V}, 15 \mathrm{~min}$; gradient to $600 \mathrm{~V}, 10 \mathrm{~min}$; $600 \mathrm{~V}, 15 \mathrm{~min}$; gradient to $1500 \mathrm{~V}, 10 \mathrm{~min} ; 1500 \mathrm{~V}$, $30 \mathrm{~min}$; gradient to $3000 \mathrm{~V}, 20 \mathrm{~min} ; 3000 \mathrm{~V}, 210 \mathrm{~min}$; pause on $50 \mathrm{~V}$ ). Strips were afterwards either kept at $-80^{\circ} \mathrm{C}$ until further use or used immediately for second-dimension separation. IPG-strips were equilibrated beforehand for $15 \mathrm{~min}$ in $6.48 \times 10^{-2} \mathrm{M}$ DTT and then for $15 \mathrm{~min}$ in $0.216 \mathrm{M}$ iodoacetamide solution, dissolved in equilibration buffer $(6 \mathrm{M}$ urea, $30 \%$ [w/v] glycerol, $69.2 \times 10^{-3} \mathrm{M}$ SDS in $0.05 \mathrm{M}$ Tris-HCl buffer, $\mathrm{pH}$ 8.8). Molecular weight separation was conducted on a Biorad Mini-Protean ${ }^{\circledR}$ Tetra System $(50 \mathrm{~V}, 10 \mathrm{~min}, 110 \mathrm{~V}$ thereafter) via a $12.5 \%$ acrylamide concentrated polyacrylamide gel. The resulting gel was Coomassie ${ }^{\circledR}$ stained for $20 \min (45 \%$ [v/v] methanol, $10 \%$ acetic acid, $2.93 \times 10^{-3} \mathrm{M}$ Coomassie ${ }^{\circledR}$ Brilliant Blue G-250) and further treated in corresponding destaining solution $(10 \%[\mathrm{v} / \mathrm{v}]$ acetic acid, 5\% [v/v] 2-propanol). Destained gels were scanned (600 dpi resolution) and analyzed for differential protein patterns using Delta 2D software (Decodon). Gels resulting from bacterial co-cultivation with diatom supernatant were set as reference gels (REF I-III), and those gels resulting from cocultivation with diatoms (treatment; TRE I-III) were compared to the reference gels (Fig. 1). Only significant results $(p<0.05)$ based on 3 replicates with at least 2-fold changes were considered (2-fold upregulation, 0.5 -fold down-regulation). Statistical analysis was conducted using the Delta 2D software package. All results were manually reviewed with respect to correct spot definition and warping.

\section{Matrix-assisted laser desorption/ionization-time of flight mass spectrometry (MALDI-TOF MS) analysis}

Protein spots of interest were excised from SDS gels, chopped into small pieces, and washed twice for $15 \mathrm{~min}(2 \times 15 \mathrm{~min})$ in $100 \mu \mathrm{l}$ of $0.05 \mathrm{M}$ ammonium bicarbonate buffer, containing $50 \%$ acetonitrile (v/v). Gel pieces were finally dehydrated by addition of $500 \mu \mathrm{l}$ acetonitrile. After decanting and short airdrying, samples were further treated with trypsin digestion buffer (Promega) according to Shevchenko et al. (2006). Fast tryptic digest was carried out by incubation of samples at $55^{\circ} \mathrm{C}$ for $30 \mathrm{~min}$ (Shevchenko et al. 2006). Sample supernatant was directly used for MALDI-TOF MS analysis. The supernatant was mixed in a 1:1 ratio with a saturated $\alpha$-cyano-4hydroxycinnamic acid solution beforehand (prepared in $30 \%$ acetonitrile, $0.5 \%$ TFA; non-dissolved matrix solids were removed by centrifugation $(15 \mathrm{~min}, 16100 \times g)$. An AutoflexII TOF/TOF mass spectrometer (Bruker Daltonics) was used according to standard parameters (acquisition range 840$4000 \mathrm{Da}$; signal-to-noise ratio $=6$, in specific cases 3 ; error range $50 \mathrm{ppm}$; allowed mis-cleavages $=1$; potential modifications 'Oxidation $\left.(\mathrm{M})^{\prime}\right)$. Peptide masses derived from trypsin auto digestion were used for calibration $(842.50940 ; 1045.56370 ; 1713$. 80840; 1774.89750; 2083.00960; 2211.10400; 2283. $18020 \mathrm{Da})$. Obtained mass lists were identified using the MASCOT search engine (Perkins et al. 1999). The presence of 2 proteins within 1 protein gel spot was tested and ruled out as follows. When peptide masses were identified in the mass spectrum that could not be assigned to the obtained protein identification, these unassigned peptides were re-searched via the MASCOT search engine, thus potentially identifying any second protein in the spot. All results were reviewed with respect to the identified organism and expected molecular weight as retrieved from SDS-PAGE.

\section{Screening for metabolizable carbon sources in liquid and on solid medium}

The use of potential carbon sources of M. adhaerens HP15 was tested both in liquid and on solid medium. We prepared $5 \mathrm{~g} \mathrm{l}^{-1}$ of a compound in $75 \%$ NSW, containing additions of $3.62 \times 10^{-2} \mathrm{M} \mathrm{NaH}_{2} \mathrm{PO}_{4}$ - $2 \mathrm{H}_{2} \mathrm{O}, 1 \times 10^{-3} \mathrm{M} \mathrm{NH}_{4} \mathrm{Cl}$, and trace elements as used for $\mathrm{f} / 2$ medium. The $\mathrm{pH}$ was adjusted to 7.6 with $1 \mathrm{M}$ $\mathrm{NaOH}$ solution. Beforehand, bacterial cells were grown, harvested, and washed as described above. 
Liquid incubations were started at an OD of 0.05. A negative control containing no carbon source was prepared as a reference. Medium as described above containing glutamate was used as a positive control. In the case of solid medium, $12 \mathrm{~g} \mathrm{l}^{-1}$ agar was added. Streaks on agar plates were conducted with prewashed cells as described above (OD 0.05).

We tested 21 carbohydrates, 17 amino acids, 2 protein-associated compounds, and 12 further compounds as potential carbon sources. Specifically, 10 monosaccharides $(\mathrm{L}(+)$-arabinose, galactose, $\mathrm{N}$ acetyl-D-glucosamine, fructose, D(+)-fucose, D-maltose, $\mathrm{D}(+)$-mannose, N-acetyl-D-mannosamin, L(+)rhamnose, D(+)-xylose), 3 disaccharides (lactose, D-maltose, and D(+)-sucrose), 1 trisaccharide (raffinose), and 7 polysaccharides (alginic acid, carboxymethyl-cellulose, carrageenan, cellulose, chitin, dextrin, and xylan) were tested. The tested amino acids and protein-associated compounds were alanine, L-arginine, L-asparagine, cystein, glutamate, glutamine, glycine, isoleucine, histidine, leucine, lysine, methionine, proline, phenylalanine, serine, Lthreonine, and valine, as well as bovine serum albumin $\mathrm{V}$ and a casamino acid mix. Further compounds tested were acetate, butyrate, citrate, lecithin, malate, nicotininc acid, octanoic acid, putrescine, propionate, pyruvate, spermidine, and succinate. For amino acids, experiments were additionally conducted under supplementation of another carbon source known to support growth (5 $\mathrm{g} \mathrm{l}^{-1}$ glutamate). This additional test aimed to determine any potential toxic effects on the bacterium caused by the provided amino acid.

Growth behavior was determined after $72 \mathrm{~h}$ of incubation. In liquid culture, visible growth was determined as an increase in OD in comparison to the negative control. To verify actual growth of $M$. adhaerens HP15 in liquid culture (and to rule out contamination), test streaks on MB medium of all positive samples were further carried out, and the expected morphology was observed after a repeated incubation and colony formation. On solid medium, positive growth was determined by the formation of colonies, showing the expected morphology of $M$. adhaerens HP15.

\section{Databases used for protein and sequence interpretation}

Information on available metabolic pathways and uptake systems of $M$. adhaerens HP15, as well as gene cluster analysis, was retrieved from the Kyoto
Encyclopedia of Genes and Genomes (KEGG) website (Kanehisa \& Goto 2000). Proteins and gene loci of the bacterium were obtained from the National Center of Biotechnology Information (NCBI) website, where the full genome sequence of the bacterium is available (CP001978.1 [chromosome]; CP001979.1 [plasmid pHP-42]; CP001980.1 [plasmid pHP-187]). Gene and protein similarity searches were conducted, using the Basic Local Alignment Search Tool (BLAST) program offered by NCBI. Further information on proteins of $M$. adhaerens HP15 involved in carbohydrate utilization was derived from the carbohydrate-active enzymes (CAZy) database (Cantarel et al. 2009, Lombard et al. 2014).

\section{RESULTS}

\section{Cell numbers after termination of co-cultivation experiment}

Marinobacter adhaerens HP15 cells were incubated with the supernatant of a diatom culture ('reference') or the diatom culture itself ('treatment') (Fig. 1) for $66.5 \mathrm{~h}$. At time point 0 , the cell numbers were $6.0 \times 10^{8} \mathrm{cells} \mathrm{ml}^{-1}\left( \pm \mathrm{SD}\right.$ of $6.0 \times 10^{7}$ cells ml$\left.{ }^{-1}\right)$ for the references and $5.4 \times 10^{8}$ cells ml ${ }^{-1}( \pm 1.1 \times$ $10^{8}$ cells ml${ }^{-1}$ ) for the treatments. The obtained cell numbers upon sampling of both protocols did not differ significantly (2-sample $t$-test; $\mathrm{p}<0.05)$, with $2.6 \times$ $10^{9} \mathrm{cells} \mathrm{ml}^{-1}\left( \pm 7.1 \times 10^{8} \mathrm{cells} \mathrm{ml}^{-1}\right)$ for the references and $3.6 \times 10^{9} \mathrm{cells} \mathrm{ml}^{-1}\left( \pm 3.3 \times 10^{8} \mathrm{cells} \mathrm{ml}^{-1}\right)$ for the treatments. The growth status marked the late exponential to early stationary phase. The high bacterial number was chosen to obtain a sufficient amount of protein, and should be kept in mind when drawing conclusions on environmental aspects. The culture volume of $\sim 200 \mathrm{ml}$ was used for extraction of bacterial proteins. Diatom cultures grew from $7.62 \times$ $10^{5}$ cells ml $^{-1}\left( \pm 4 \times 10^{4}\right.$ cells ml $\left.^{-1}\right)$ at the beginning of the incubation to $1.92 \times 10^{6}$ cells ml $^{-1}\left( \pm 7.4 \times 10^{5}\right.$ cells $\mathrm{ml}^{-1}$ ) after $66.5 \mathrm{~h}$.

\section{Changes in the bacterial protein pattern during co-cultivation}

Glutamate was added to the experimental set-up to provide sufficient carbon and nitrogen for the de novo synthesis of proteins by $M$. adhaerens HP15 in response to the diatom. The exposure of $M$. adhaerens HP15 towards Thalassiosira weissflogii led to a set of significant changes in certain protein 
abundances. In summary, 10 proteins were at least 2-fold up- or down-regulated during co-cultivation of bacteria with diatom cells (treatment, Fig. 1) in comparison to the reference (Table 1 ; see also Table S1 and Fig. S1 in the Supplement at www. int-res.com/articles/suppl/a078p065_supp.pdf). This rather low yield of altered proteins was assumed to be the effect of (1) the 2D-gel parameters used (small SDS gels of $7 \mathrm{~cm}$ width, Coomassie ${ }^{\circledR}$ staining as a moderately sensitive staining method), (2) the general challenge of identifying significant proteomic alterations on 2D-gels obtained from biological systems, and (3) the focus on the cytoplasmic protein fraction (as opposed to e.g. the membrane fraction or the secretome in addition).

Gene products of $M$. adhaerens HP15 encoding 2 alcohol dehydrogenases (ADP98924.1 and ADP98928.1) and 1 aldehyde dehydrogenase (ADP98908.1) were down-regulated when diatom cultures were present. Notable for these 3 genes is their close proximity in the genome sequence. The aldehyde dehydrogenase gene is separated from the 2 loci comprising the alcohol dehydrogenase genes by 15 genes, while the latter 2 genes are separated by only 3 additional genes (Table 1 and Fig. S2, the latter in the Supplement). Due to close proximity of these genes, a cluster analysis for this genomic region was conducted to eventually deduce functional genomic embedment of the respective gene products. The cluster analysis function of the KEGG website was used for this purpose. Results showed that the corre- sponding genomic region is separated into 6 different clusters. Importantly, the 3 genes encoding the down-regulated proteins are not encoded in the same cluster (Fig. S2). However, a number of genes in this locus encode proteins that are associated with metabolic functions on, and uptake systems for, nitrogen-rich compounds. Examples of this are urea carboxylase-associated proteins (ADP98910.1, ADP98911.1) and a urea amidolyase-like protein (ADP98913.1), a glutamate-ammonia ligase (ADP98920.1), a spermidine/putrescine $\mathrm{ABC}$ transporter ATPase (ADP98923.1), and the homoserine O-acetyltransferase MetX involved in cysteine and methionine metabolism (ADP98921.1) (Table S2 in the Supplement).

Three additional genes that were down-regulated in $M$. adhaerens HP15 when encountering diatom cells code for an isocitrate lyase potentially involved in the glyoxylate cycle (ADP98998.1), a 3-hydroxyisobutyrate dehydrogenase putatively involved in valine catabolism (ADP98998.1), and a transporter component which may be involved in short-chain amide uptake, possibly also branched amino acid uptake (ADP98645.1) (Table 1). By additional BLAST analysis, the latter transporter component was identified as the UrtA component of a urea transporter.

Four $M$. adhaerens HP15 proteins were identified as being up-regulated during co-cultivation with the diatom (Table 1). Two of these proteins are encoded by genes located in close proximity to each other on the genome, suggesting their functional

Table 1. Proteins of Marinobacter adhaerens HP15 cell lysate, found to be at least 2-fold up- or down-regulated during co-cultivation with the diatom Thalassiosira weissflogii

\begin{tabular}{lllc}
\hline Identified protein (annotation according to NCBI) & \multicolumn{1}{c}{ Additional information } & Accession no. & EC no. \\
\hline Down-regulated & & ADP98924.1 & 1.2 .1 .8 \\
Quinoprotein alcohol dehydrogenase & Alcohol <-> aldehyde & ADP98928.1 & 1.2 .1 .8 \\
Low-quality protein: quinoprotein alcohol dehydrogenase & Alcohol <-> aldehyde & ADP98908.1 & $1.2 .1 .-$ \\
NAD-dependent aldehyde dehydrogenase & Aldehyde <->alcanic acid & 4.1 .3 .1 \\
Isocitrate lyase & Isocitrate -> glyoxylate + succinate & ADP98998.1 \\
& (glyoxylate cycle) & ADP96674.1 & 1.1 .1 .31 \\
3-hydroxyisobutyrate dehydrogenase & Valine catabolism & ADP98645.1 & - \\
Urea short-chain amide or branched-chain & UrtA component of & ADP97492.1 \\
amino acid uptake ABC transporter, & urea transporter & - \\
periplasmic solute-binding protein & & ADP98795.1 \\
Up-regulated & PhnD unit of phosphonate & - \\
Phosphonate ABC transporter, & transporter & AotJ unit of an arginine/ornithine & ADP98792.1 \\
periplasmic phosphonate-binding protein & amino acid transporter & - \\
Extracellular solute-binding protein, family 3 & - & AivK unit of branched amino acid & ADP99862.1 \\
TRAP dicarboxylate family transporter, DctP subunit & uptake transporter, periplasmic & - \\
Amino acid binding protein & & & \\
\end{tabular}


coupling. These genes encode for a DctP subunit of a tripartite ATP-independent periplasmic (TRAP) dicarboxylate family transporter (ADP98792.1) and a protein annotated as extracellular solute-binding (ADP98795.1). Analysis of the latter protein using the KEGG database assigned it as the AotJ component of an arginine/ornithine amino acid transporter. Its potential function is substantiated by the presence of surrounding genes, encoding the subunit of a histidine-lysine-arginine-ornithine transporter (HisP; ADP98794.1) and 2 inner membrane permeases of arginine- and histidine-associated ABC transporters (ArtQ, ADP98796.1; and ArtM, ADP98797.1).

The third bacterial protein up-regulated during cocultivation with diatoms was annotated as a periplasmic substrate-binding protein of an $\mathrm{ABC}$ transporter and might be a homolog of the PhnD unit of an ABC phosphonate transporter (ADP97492.1). This assumption is supported by the presence of genes encoding for the 2 other transporter components PhnC (ADP97493.1) and PhnE (ADP97494.1) within the same gene cluster.

The fourth of the up-regulated M. adhaerens HP15 proteins was annotated as an amino acid-binding protein (ADP98795.1), likely being a homolog of the periplasmic LivK unit of a branched amino acid uptake transporter. Again, a functional involvement of this protein in branched amino acid transport is supported by the close proximity of genes, encoding the inner membrane translocators LivH and LivG as well as the ATP-binding components LivM and LivF (Adams et al. 1990).

In summary, the proteomics analysis suggested that genes encoding for proteins involved in amino acid uptake or utilization were affected in their expression when $M$. adhaerens HP15 was co-cultivated with diatom cells.

\section{Analysis of carbon source utilization of M. adhaerens HP15}

In order to experimentally support some of the proteomics findings, a set of organic compounds such as diverse carbohydrates, amino acids, and other molecules like short-chained fatty acids were tested as potential sole carbon sources of M. adhaerens HP15.

Among all tested carbohydrates, fructose was the only one that facilitated growth of the bacterium in both liquid and solid medium (Table 2). The analysis of data retrieved from KEGG showed that the majority of classical mono- or oligosaccharide trans- porters could not be identified in $M$. adhaerens HP15 (Tables S3 \& S4 in the Supplement). Interestingly, genes encoding a fructose uptake system were also not identified (Table S4), probably assuming the presence of a different system for fructose uptake. To test if potential genes were missed by the applied KEGG program, fructose uptake system genes of other proteobacteria were directly blasted against the genome of $M$. adhaerens HP15 but did not reveal any similarities. Focusing on phosphotransferase systems, genes encoding for phosphotransferases are only present in the case of a fructose phosphatase system but not in other saccharide phosphatase systems (Table S5 in the Supplement). This information might support the experimental finding that exclusively fructose and no other carbohydrate was metabolized by the bacterium.

Subsequently, using the CAZy database, we screened for genes associated with carbohydrate utilization. In total, 64 proteins encoded within the $M$. adhaerens HP15 genome were identified to be associated with carbohydrate utilization and sub-classified as glycoside hydrolases, glycosyl transferases, polysaccharide lyases, carbohydrate esterases, and the carbohydrate-binding module family (Table 3 ). For comparison, we additionally retrieved the information for carbohydrate-utilizing proteins of the marine bacterium Flavobacterium johnsoniae UW101 (McBride et al. 2009), a representative of the Bacteroidetes group known to degrade algal polysaccharides. For this bacterium, a total of 279 carbohydrate utilization-associated genes were found (Table 3). This suggests that the high number of carbohydrateactive enzymes in F. johnsoniae UW101 fairly well represents the metabolic profile and capabilities of this bacterium as an algae polysaccharide-associated organism, whereas M. adhaerens HP15 appears less adapted to polysaccharide catabolism.

Whilst the majority of carbohydrates were apparently not metabolized by M. adhaerens HP15, certain amino acids and protein-associated compounds turned out to be growth-supporting for the bacterium. These amino acids were alanine, L-arginine, L-asparagine, glutamic acid, glutamine, isoleucine, leucine, lysine, proline, and phenylalanine (Table 2). The bacterium further grew on bovine serum albumin V and lecithin as the sole carbon source. Glycine proved to be cell toxic at the concentrations used, as the bacterium did not grow in its presence, nor in the presence of both glycine and a second metabolizable carbon source. Other non-metabolized amino acids did not show any inhibitory effects. 
Table 2. Compounds tested as potential carbon sources for Marinobacter adhaerens HP15

\begin{tabular}{|c|c|c|c|}
\hline Compound & & Metabolized by $M$. adhaerens HP15 & Not metabolized by $M$. adhaerens HP15 \\
\hline \multirow[t]{4}{*}{ Carbohydrates } & Monosaccharides & Fructose & $\begin{array}{l}\text { L(+)-arabinose, galactose, } \\
\text { N-acetyl-D-glucosamine, D(+)-fucose, } \\
\text { D-maltose, D(+)-mannose, } \\
\text { N-acetyl-D-mannosamine, } \\
\text { L(+)-rhamnose, D(+)-xylose }\end{array}$ \\
\hline & Disaccharides & - & $\begin{array}{l}\text { Lactose (D-glucose \& D-galactose; } \beta-1-4), \\
\text { D-maltose (degradation product of starch), } \\
\text { D(+)-sucrose ( } \alpha \text {-D-glucose \& } \beta \text {-D-fructose) }\end{array}$ \\
\hline & Trisaccharides & - & Affinose (galactose, glucose, fructose) \\
\hline & Polysaccharides & - & $\begin{array}{l}\text { Alginic acid, carboxymethyl-cellulose, } \\
\text { carrageenan, cellulose, chitin, } \\
\text { dextrin (D-glucose, } \alpha(1-4) \text { or } \\
\alpha(1-6) \text { linkage), xylan }\end{array}$ \\
\hline Amino acids & & $\begin{array}{l}\text { Alanine, L-arginine, L-asparagine, } \\
\text { glutamate, glutamine, isoleucine, } \\
\text { leucine, lysine, proline, } \\
\text { phenylalanine }\end{array}$ & $\begin{array}{l}\text { Cystein, glycine }{ }^{\mathrm{a}} \text {, histidine, methionine, } \\
\text { serine, L-threonine, valine }\end{array}$ \\
\hline $\begin{array}{l}\text { Protein-associated } \\
\text { compounds }\end{array}$ & & $\begin{array}{l}\text { Bovine serum albumin fraction } \mathrm{V}, \\
\text { casamino acids }\end{array}$ & - \\
\hline $\begin{array}{l}\text { Further compounds } \\
\text { tested }\end{array}$ & & $\begin{array}{l}\text { Acetate, butyrate, citrate, lecithin, } \\
\text { malate, propionate, pyruvate, } \\
\text { succinate }\end{array}$ & $\begin{array}{l}\text { Nicotinic acid, octanoic acid, } \\
\text { putrescine, spermidine }\end{array}$ \\
\hline
\end{tabular}

Table 3. Number of carbohydrate-utilizing gene products of Marinobacter adhaerens HP15 and Flavobacterium johnsoniae UW101. Numbers were retrieved from the CAZy database. GH: glycoside hydrolase family; GT: glycosyl transferase family; PLF: polysaccharide lyase family; CE: carbohydrate esterase family; CBM: carbohydrate-binding module family

\begin{tabular}{|lccccccc|}
\hline Organism & GH & GT & PLF & CE & CBM & Sum & $\%$ of total genes \\
\hline M. adhaerens HP15 & 15 & 41 & 0 & 1 & 7 & $\mathbf{6 4}$ & 1.43 \\
F. johnsoniae UW101 & 156 & 64 & 11 & 18 & 30 & $\mathbf{2 7 9}$ & 5.41 \\
\hline
\end{tabular}

\section{DISCUSSION}

Previously, only a few studies have been conducted to better understand bacteria-diatom interactions by using in-depth approaches based on in vitro co-cultivations. Paul et al. (2013) conducted cocultivation studies with Dinoroseobacter shibae and the diatom Thalassiosira pseudonana, mainly focusing on intracellular metabolites, whereas Bruckner et al. (2011) focused on extracellular proteins in cocultivations of different freshwater diatom species with a set of bacterial strains. Amin et al. (2015) have thus far conducted the most comprehensive study on bacteria-diatom interactions, combining information gained from transcriptomics data of both co-cultivated partners with metabolomics data.
Genes and metabolites possibly playing a role during a specific diatom-bacteria interaction were identified. A number of environmental metatranscriptomic and metabolomic data sets were further screened for the presence of identified metabolites and the expression of genes involved in their synthesis pathways.

Interestingly, none of these studies had dealt with the cytoplasmic proteome of the bacterial interaction partner. In the current study, we hypothesized that a physical interaction of both organisms in the phycosphere of the diatom is not needed for an exchange of nutrients or signals. Consequently, the 2 interaction partners were separated by dialysis tubing allowing free diffusion of compounds. 
The experimental set-up included the addition of glutamate. This compound was primarily added to guarantee sufficient carbon and nitrogen supply for the synthesis of proteins by Marinobacter adhaerens HP15. This approach aimed to avoid artifacts in the proteomic pattern caused due to e.g. limiting conditions instead of the actual response to the diatom or diatom-borne compounds. As both references and treatments showed similar bacterial growth, it may be concluded that glutamate was used as the main metabolized carbon source, while diatom exudates such as TEP played only a minor role. However, when applying this set-up, we assumed that the interaction of $M$. adhaerens HP15 with $T$. weissflogii is not an interaction wherein the diatom simply provides carbon to the bacterium, e.g. in form of released TEP. In the latter case, addition of glutamate would have led to a decoupling of the interaction. Irrespective of this, easy availability of a carbon source may indeed have impacted the number of differentially expressed proteins. Furthermore, it cannot be ruled out that the mixotrophic growth of the diatom might have been induced by the presence of glutamate.

\section{M. adhaerens HP15 is not a carbohydrate degrader}

In individual cases, up to $80 \%$ of algal exudates are made up of carbohydrates (Myklestad et al. 1989, Myklestad 1995, Biddanda \& Benner 1997) that are often regarded as classical bacterial attractants (Seymour et al. 2008). Common sugars identified in such extracellular matrices may be specific for a given algal species and its respective growth state (Bruckner et al. 2011). Arabinose, fucose, glucose, galactose, mannose, rhamnose, and xylose were identified as such sugars (Biersmith \& Benner 1998). Consequently, the majority of these carbohydrates were considered experimentally in the present study. Certain bacterial groups, such as members of the Bacteroidetes, are known for their ability to degrade carbohydrate compounds resulting from algae exudates (Teeling et al. 2012, Hahnke et al. 2013, Mann et al. 2013). According to our proteomics and carbon utilization results, none of the tested carbohydrates was used as a carbon source by $M$. adhaerens HP15 except for fructose. In support of this, the proteomics approach did not show any carbohydrate uptake systems or carbohydrate-utilizing proteins being upregulated in $M$. adhaerens HP15 in the presence of the diatom. The findings were further substantiated by the remarkably low number of carbohydrate uti- lization-associated proteins encoded by the genome of $M$. adhaerens HP15, as compared to those of classical degraders of algae exudates, such as Flavobacterium johnsoniae UW101 (McBride et al. 2009) or other members of the Flavobacteria (Mann et al. 2013).

\section{Shifts in protein patterns suggest a favorable nutrient state during co-cultivation}

Expression of 1 aldehyde and 2 quinoprotein alcohol dehydrogenases was apparently down-regulated in $M$. adhaerens HP15 during co-cultivation. Such enzymes usually facilitate the oxidation of alcohols via aldehydes towards alkanoic acids. Interestingly, the respective down-regulated dehydrogenase genes are located in a genomic region that also encodes a number of proteins, associated with the utilization of nitrogen-rich molecules such as urea, amino acids, spermidine, and putrescine. We tested whether these proteins are organized in a gene cluster. However, this hypothesis was not confirmed, since the genomic region of concern is divided into different clusters, from which a functional relationship could not be easily retrieved. A functional hint, however, becomes apparent when looking at homologous genes in another marine bacterium: the $\gamma$-proteobacterium Alteromonas sp. KE10 expresses the aldehyde dehydrogenase OlgA (BAA24014.1) during low-nutrient stress. During high-nutrient conditions, this dehydrogenase was found to be down-regulated (Maeda et al. 2000). The aldehyde dehydrogenase ADP98908.1 of $M$. adhaerens HP15 that was downregulated in the presence of the diatom shows a $74 \%$ protein identity to OlgA of Alteromonas sp. KE10. Therefore, diatom presence might represent a favorable nutrient status for the bacterium.

Isocitrate lyase is a central enzyme in the glyoxylate cycle that was also down-regulated in the bacterium during co-cultivation with the diatom. In the case of a suppression of the tricarboxylic acid (TCA) cycle due to e.g. unfavorable nutrient supply or limited availability of specific carbon compounds, the glyoxylate cycle may short-cut the reaction from isocitrate via $\alpha$-ketoglutarate and succinyl-CoA to succinate (as it would happen in the TCA cycle) in a single-step reaction. Isocitrate lyase represents a branching point in this cycle due to the reaction of isocitrate to succinate and glyoxylate (Betts et al. 2002). While glyoxylate continues fueling the glyoxylate cycle, succinate replenishes the TCA cycle (Vanni et al. 1990). The relevance of isocitrate lyase, 
and consequently the importance of the glyoxylate cycle in surviving nutrient-depleted conditions, had been demonstrated previously (Idnurm \& Howlett 2002, Gengenbacher et al. 2010). The down-regulation of a central enzyme of the glyoxylate cycle thus indicates a favorable substrate supply to the TCA cycle. Consequently, the bacterial cell metabolism might be provided with a richer nutrient source, or a signal representing such, during co-cultivation with the diatom as compared to the growth in the reference medium. Contradictory to this hypothesis is the observation that cell numbers of M. adhaerens HP15 did not change during sampling. The glyoxylate cycle is also activated during exclusive supply of acetate or fatty acids and will be shut down upon addition of other carbon sources (Cronan \& Laporte 2006). However, the reference treatment was supplied with glutamate as the sole carbon source, which does not directly explain the presence of isocitrate lyase and induction of the glyoxylate cycle. An analysis of metabolites available in both the culture medium and intracellularly (as e.g. done by Paul et al. 2013) may add valuable information to the understanding of this finding.

We further observed the down-regulation of the periplasmic substrate-binding compound UrtA of the urea uptake system (Beckers et al. 2004). Urea serves as a nitrogen source for a wide range of bacteria (Mobley \& Hausinger 1989). The operon encoding for the urea uptake system (made up of 5 genes, urt$A B C D E$ ) is induced by nitrogen-limiting conditions in Corynebacterium glutamicum (Beckers et al. 2004). Due to the down-regulation of 1 protein of the urea uptake system, the nitrogen supply seems to be more optimal in the treatment protocol as compared to the reference protocol in which the amino acid glutamate is the only nitrogen source provided.

The enzyme 3-hydroxyisobutyrase dehydrogenase (EC 1.1.1.31), less expressed in the presence of the diatom, is part of the valine degradation pathway and oxidizes 3-hydroxyisobutyrate to methylmalonate semialdehyde (Robinson \& Coon 1957, Bannerjee et al. 1970). Reduced expression of a respective gene might suggest that the bacterium was not in need of valine utilization as a carbon or nitrogen source during co-cultivation. However, since the corresponding protein was present when only glutamate was provided (Débarbouillé et al. 1991) it is assumed that in the reference protocol, probably nitrogen and carbon became more limiting. Alternatively, nitrogen supply might be balanced during co-cultivation of $M$. adhaerens HP15 with the diatom. This hypothesis is in line with the down- regulation of a urease uptake system, and leads to the conclusion that the diatom might provide an additional source of nitrogen to the bacterium.

\section{Compounds gained by M. adhaerens HP15 during co-cultivation with the diatom $T$. weissflogii}

According to the current results, proteins, peptides, or amino acids might be the major carbon sources of the bacterium. Their presence in exopolymeric substances has been shown in previous studies (Myklestad et al. 1989, Myklestad 1995, Biddanda \& Benner 1997).

During exposure to the diatom, a possible benefit for $M$. adhaerens HP15 might be the release of specific amino acids by the diatom. Two bacterial proteins up-regulated while being co-cultivated with $T$. weissflogii can be associated with amino acid uptake and facilitate the binding of amino acids in the periplasm. LivK is part of a branched amino acid uptake system transporting leucine, isoleucine, and valine (Adams et al. 1990, Ribardo \& Hendrixson 2011). AotJ, another amino acid-binding protein, belongs to an arginine/ornithine uptake system (Wissenbach et al. 1995, Nishijyo et al. 1998). A third up-regulated transport-associated protein, a DctP subunit, could not be assigned to a substrate, but is suspected to be part of the above mentioned arginine/ornithine transporter due to the close proximity of the corresponding genes. Amino acids other than glutamate might serve as possible additional carbon and nitrogen sources when diatoms are present, suggesting that several of such amino acids might be secreted by the diatom cells. This finding is supported by the down-regulation of a urea uptake transporter element during co-cultivation with the diatom, a process usually associated with growth under nitrogen-rich conditions (Beckers et al. 2004). Only 1 protein of a whole transporter unit, which comprises several proteins, was found to be altered (Beckers et al. 2004). This observation may be partly explained by our experimental approach that did not isolate and identify membrane-associated, hydrophobic proteins (e.g. UrtB and UrtC, LivH and LivK, and AotQ and AotM), which thus were not represented in the cytoplasmic protein fraction that we analyzed.

Previous studies support our hypothesis of amino acids playing a major role during bacteria-diatom interactions: Sulfitobacter sp. SA11 received tryptophan from its diatom partner and provided IAA to the host organism (Amin et al. 2015). It was 
assumed that tryptophan was even directly used for the synthesis of IAA in the bacterium, underlining the closely coupled trade-off between the partners. Paul et al. (2013) found that intracellular free amino acid concentrations were increased in T. pseudonana during exposure to D. shibae. Alterations in the concentration of extracellular free amino acids were also observed in co-cultivations of mainly benthic freshwater diatoms towards different bacterial strains (Bruckner et al. 2011). Gärdes et al. (2012) confirmed for T. weissflogii cultures that the quantity and quality of both dissolved free and dissolved combined amino acids is highly dependent on the nutrient status of the culture. Further, the axenic or xenic status (being co-cultivated with $M$. adhaerens HP15) of the culture impacted the net concentration of free and combined amino acids (Gärdes et al. 2012). A shift in amino acid composition during phosphate-depleted conditions was observed, irrespective of the culture being xenic or axenic. The proportions of the branched amino acids leucine and isoleucine-but not of valine-in the total amino acid pool increased during phosphate limitation. Specifically, the ratio of leucine and isoleucine as part of total dissolved free amino acids increased from $\sim 5 \%$ in both nutrient-balanced and nitrogendepleted scenarios to $\sim 30 \%$. Indeed, indications for a phosphate limitation were identified in the present study: an ABC type transporter component, a phosphonate substrate binding unit (PhnD), was up-regulated in $M$. adhaerens HP15 in the presence of the diatom. The $p h n D$ gene was previously shown to be induced during phosphate-limiting conditions (Metcalf \& Wanner 1991, Gebhard et al. 2006). This finding would further explain and support the up-regulation of the LivK subunit as part of an uptake transporter for branched amino acids in the presence of diatom cells in the current study. In addition, an enzyme as part of the valine degradation pathway is down-regulated, which would be in line with the low presence of valine during phosphate limitation in comparison to other branched amino acids. However, whether the release of such amino acids by the diatom is indeed due to phosphate limitation, as suggested by Gärdes et al. (2012), remains speculative and deserves further investigation.

An obvious and unsolved question is why diatoms actively release high-value metabolites, such as amino acids, when coming into contact with certain bacteria. One possible explanation is a potential trade-off: the diatom provides a high nutrient investment in order to trigger attachment of certain bacte- ria. In turn, these bacteria might be favorable for the diatom by providing a metabolite to which the diatom is auxotrophic. Such a metabolite remains to be identified in further experiments. Amin et al. (2015) already demonstrated such a metabolite: they observed a supply of tryptophan by the diatom, whereas the bacterium provided the diatom with the plant hormone IAA.

Our results suggest that $M$. adhaerens HP15 might benefit from diatom-borne amino acids. A potential benefit of this interaction for the diatom could be the supply of vitamins by the bacterium. Cobalamin (vitamin $B_{12}$ ) has been postulated as such a potential candidate (Cole 1982, Croft et al. 2005). However, the genome analysis of $M$. adhaerens HP15 revealed that this organism does not synthesize cobalamin, but might produce a set of other vitamins that may determine synergistic bacteria-diatom interactions (Croft et al. 2006, Wagner-Döbler et al. 2010), which deserves future investigations.

\section{CONCLUSIONS}

Herein, a proteomics approach combined with a screening for carbon substrate preferences was chosen to investigate processes taking place in a bacterial cell during its interaction with a diatom. The approach allowed the interpretation of characteristics during the interaction. Our results underline the importance of amino acids as a 'traded' component group serving as a nitrogen and carbon source for bacteria. The role of Marinobacter adhaerens HP15 was further defined as being involved in amino acid-, peptide-, or protein-associated turn-over processes. A potential role of algal TEP as a source of amino acids or peptides remains to be investigated in future studies. The actual benefits for the diatom are so far unknown for this model. Therefore, future studies should also aim to include proteome analysis of the diatom to better understand adaptions taking place in this organism during interaction with bacteria. Integrating the analysis of further protein fractions like the membrane or extracellular fraction will improve and substantiate our results. Corresponding studies should also be extended to a metabolic analysis of bacteria-diatom interactions in order to develop a mechanistic understanding of the process.

Acknowledgements. This project was funded by the Helmholtz Graduate School for Polar and Marine Research (POLMAR) and the Deutsche Forschungsgemeinschaft (UL169/6-1). 


\section{LITERATURE CITED}

Adams M, Wagner L, Graddis T, Landick R, Antonucci T, Gibson A, Oxender D (1990) Nucleotide sequence and genetic characterization reveal six essential genes for the LIV-I and LS transport systems of Escherichia coli. J Biol Chem 265:11436-11443

Alldredge AL, Gotschalk CC (1989) Direct observations of the mass flocculation of diatom blooms: characteristics, settling velocities and formation of diatom aggregates. Deep-Sea Res A Oceanogr Res Pap 36:159-171

Amin SA, Green DH, Hart MC, Kuepper FC, Sunda WG, Carrano CJ (2009) Photolysis of iron-siderophore chelates promotes bacterial-algal mutualism. Proc Natl Acad Sci USA 106:17071-17076

Amin SA, Parker MS, Armbrust EV (2012) Interactions between diatoms and bacteria. Microbiol Mol Biol Rev 76:667-684

Amin SA, Hmelo LR, van Tol HM, Durham BP and others (2015) Interaction and signalling between a cosmopolitan phytoplankton and associated bacteria. Nature 522: 98-101

Azam F, Malfatti F (2007) Microbial structuring of marine ecosystems. Nat Rev Microbiol 5:782-791

* Azam F, Smith D, Steward G, Hagstrom A (1994) Bacteriaorganic matter coupling and its significance for oceanic carbon cycling. Microb Ecol 28:167-179

Baker LJ, Kemp PF (2014) Exploring bacteria-diatom associations using single-cell whole genome amplification. Aquat Microb Ecol 72:73-88

Bannerjee D, Sanders LE, Sokatch JR (1970) Properties of purified methylmalonate semialdehyde dehydrogenase of Pseudomonas aeruginosa. J Biol Chem 245:1828-1835

Beauvais S, Pedrotti ML, Egge J, Iversen K, Marrasé C (2006) Effects of turbulence on TEP dynamics under contrasting nutrient conditions: implications for aggregation and sedimentation processes. Mar Ecol Prog Ser 323: 47-57

Beckers G, Bendt A, Kramer R, Burkovski A (2004) Molecular identification of the urea uptake system and transcriptional analysis of urea transporter- and ureaseencoding genes in Corynebacterium glutamicum. J Bacteriol 186:7645-7652

Behrenfeld M, Bale A, Kolber Z, Aiken J, Falkowski P (1996) Confirmation of iron limitation of phytoplankton photosynthesis in the equatorial pacific ocean. Nature 383: 508-511

Bell W, Mitchell R (1972) Chemotactic and growth responses of marine bacteria to algal extracellular products. Biol Bull (Woods Hole) 143:265-277

Betts J, Lukey P, Robb L, McAdam R, Duncan K (2002) Evaluation of a nutrient starvation model of Mycobacterium tuberculosis persistence by gene and protein expression profiling. Mol Microbiol 43:717-731

Biddanda B, Benner R (1997) Carbon, nitrogen, and carbohydrate fluxes during the production of particulate and dissolved organic matter by marine phytoplankton. Limnol Oceanogr 42:506-518

Biersmith A, Benner R (1998) Carbohydrates in phytoplankton and freshly produced dissolved organic matter. Mar Chem 63:131-144

Blackburn N, Fenchel T, Mitchell J (1998) Microscale nutrient patches in planktonic habitats shown by chemotactic bacteria. Science 282:2254-2256

* Bowler C, Allen AE, Badger JH, Grimwood J and others
(2008) The Phaeodactylum genome reveals the evolutionary history of diatom genomes. Nature 456:239-244

*Batbak G, Thingstad TF (1985) Phytoplankton-bacteria interactions: an apparent paradox? Analysis of a model system with both competition and commensalism. Mar Ecol Prog Ser 25:23-30

* Bruckner CG, Rehm C, Grossart H, Kroth PG (2011) Growth and release of extracellular organic compounds by benthic diatoms depend on interactions with bacteria. Environ Microbiol 13:1052-1063

Cantarel BL, Coutinho PM, Rancurel C, Bernard T, Lombard V, Henrissat B (2009) The carbohydrate-active enzymes database (CAZy): an expert resource for glycogenomics. Nucleic Acids Res 37:D233-D238

Cole JJ (1982) Interactions between bacteria and algae in aquatic ecosystems. Annu Rev Ecol Syst 13:291-314

* Croft MT, Lawrence A, Raux-Deery E, Warren M, Smith A (2005) Algae acquire vitamin $B_{12}$ through a symbiotic relationship with bacteria. Nature 438:90-93

Croft MT, Warren MJ, Smith AG (2006) Algae need their vitamins. Eukaryot Cell 5:1175-1183

* Cronan JE Jr, Laporte D (2006) Tricarboxylic acid cycle and glyoxylate bypassing. EcoSal Plus 2006

* Débarbouillé M, Martin-Verstraete I, Kunst F, Rapoport G (1991) The Bacillus subtilis sigL gene encodes an equivalent of sigma 54 from gram-negative bacteria. Proc Natl Acad Sci USA 88:9092-9096

* Droop MR (1970) Vitamin $B_{12}$ and marine ecology. V. Continuous culture as an approach to nutritional kinetics. Helgol Wiss Meeresunters 20:629-636

*Ducklow HW, Steinberg DK, Buesseler KO (2001) Upper ocean carbon export and the biological pump. Oceanography 14:50-58

* Eigemann F, Hilt S, Salka I, Grossart H (2013) Bacterial community composition associated with freshwater algae: species specificity vs. dependency on environmental conditions and source community. FEMS Microbiol Ecol 83:650-663

Fandino LB, Riemann L, Steward GF, Azam F (2005) Population dynamics of Cytophaga-Flavobacteria during marine phytoplankton blooms analyzed by real-time quantitative PCR. Aquat Microb Ecol 40:251-257

Field C, Behrenfeld M, Randerson J, Falkowski P (1998) Primary production of the biosphere: integrating terrestrial and oceanic components. Science 281:237-240

Foster RA, Kuypers MMM, Vagner T, Paerl RW, Musat N, Zehr JP (2011) Nitrogen fixation and transfer in open ocean diatom-cyanobacterial symbioses. ISME $\mathrm{J}$ 5: 1484-1493

*Gärdes A, Iversen MH, Grossart H, Passow U, Ullrich MS (2011) Diatom-associated bacteria are required for aggregation of Thalassiosira weissflogii. ISME J 5: 436-445

Gärdes A, Ramaye Y, Grossart HP, Passow U, Ullrich MS (2012) Effects of Marinobacter adhaerens HP15 on polymer exudation by Thalassiosira weissflogii at different $\mathrm{N}$ : P ratios. Mar Ecol Prog Ser 461:1-14

Gebhard S, Tran SL, Cook GM (2006) The Phn system of Mycobacterium smegmatis: a second high-affinity ABCtransporter for phosphate. Microbiology 152:3453-3465

Gengenbacher M, Srinivasa RPS, Pethe K, Dick T (2010) Nutrient-starved, non-replicating Mycobacterium tuberculosis requires respiration, ATP synthase and isocitrate lyase for maintenance of ATP homeostasis and viability. Microbiology 156:81-87 
Grossart HP (1999) Interactions between marine bacteria and axenic diatoms (Cylindrotheca fusiformis, Nitzschia laevis, and Thalassiosira weissflogii) incubated under various conditions in the lab. Aquat Microb Ecol 19:1-11

Grossart HP, Schlingloff A, Bernhard M, Simon M, Brinkhoff $\mathrm{T}$ (2004) Antagonistic activity of bacteria isolated from organic aggregates of the German Wadden Sea. FEMS Microbiol Ecol 47:387-396

* Grossart HP, Levold F, Allgaier M, Simon M, Brinkhoff T (2005) Marine diatom species harbour distinct bacterial communities. Environ Microbiol 7:860-873

* Guannel ML, Horner-Devine MC, Rocap G (2011) Bacterial community composition differs with species and toxigenicity of the diatom Pseudo-nitzschia. Aquat Microb Ecol 64:117-133

Guillard RRL (1975) Culture of phytoplankton for feeding marine invertebrates. In: Smith WL, Chanley MH (eds) Culture of marine invertebrate animals. Plenum, New York, NY, p 29-60

Hahnke S, Sperling M, Langer T, Wichels A and others (2013) Distinct seasonal growth patterns of the bacterium Planktotalea frisia in the North Sea and specific interaction with phytoplankton algae. FEMS Microbiol Ecol 86: 185-199

*Hecky R, Campbell P, Hendzel L (1993) The stoichiometry of carbon, nitrogen, and phosphorus in particulate matter of lakes and oceans. Limnol Oceanogr 38:709-724

* Idnurm A, Howlett BJ (2002) Isocitrate lyase is essential for pathogenicity of the fungus Leptosphaeria maculans to canola (Brassica napus). Eukaryot Cell 1:719-724

Kaeppel EC, Gärdes A, Seebah S, Grossart H, Ullrich MS (2012) Marinobacter adhaerens sp. nov., isolated from marine aggregates formed with the diatom Thalassiosira weissflogii. Int J Syst Evol Microbiol 62:124-128

Kanehisa M, Goto S (2000) KEGG: Kyoto encyclopedia of genes and genomes. Nucleic Acids Res 28:27-30

* Lombard V, Ramulu HG, Drula E, Coutinho PM, Henrissat B (2014) The carbohydrate-active enzymes database (CAZy) in 2013. Nucleic Acids Res 42:D490-D495

* Maeda T, Yoshinaga I, Shiba T, Murakami M, Wada A, Ishida Y (2000) Cloning and sequencing of the gene encoding an aldehyde dehydrogenase that is induced by growing alteromonas sp. strain KE10 in a low concentration of organic nutrients. Appl Environ Microbiol 66: 1883-1889

Mann AJ, Hahnke RL, Huang S, Werner J and others (2013) The genome of the alga-associated marine flavobacterium Formosa agariphila KMM $3901^{\mathrm{T}}$ reveals a broad potential for degradation of algal polysaccharides. Appl Environ Microbiol 79:6813-6822

Mayali X, Franks PJS, Burton RS (2011) Temporal attachment dynamics by distinct bacterial taxa during a dinoflagellate bloom. Aquat Microb Ecol 63:111-122

McBride MJ, Xie G, Martens EC, Lapidus A and others (2009) Novel features of the polysaccharide-digesting gliding bacterium Flavobacterium johnsoniae as revealed by genome sequence analysis. Appl Environ Microbiol 75:6864-6875

Metcalf WW, Wanner BL (1991) Involvement of the Escherichia coli phn (psiD) gene cluster in assimilation of phosphorus in the form of phosphonates, phosphite, $\mathrm{P}_{\mathrm{i}}$ esters, and $\mathrm{P}_{\mathrm{i}}$. J Bacteriol 173:587-600

Mobley HL, Hausinger RP (1989) Microbial ureases: significance, regulation, and molecular characterization. Microbiol Rev 53:85-108
Myklestad SM (1995) Release of extracellular products by phytoplankton with special emphasis on polysaccharides. Sci Total Environ 165:155-164

KMyklestad S, Holmhansen O, Varum KM, Volcani BE (1989) Rate of release of extracellular amino acids and carbohydrates from the marine diatom Chaetoceros affinis. J Plankton Res 11:763-773

Nishijyo T, Park S, Lu C, Itoh Y, Abdelal A (1998) Molecular characterization and regulation of an operon encoding a system for transport of arginine and ornithine and the ArgR regulatory protein in Pseudomonas aeruginosa. J Bacteriol 180:5559-5566

Passow U (2000) Formation of transparent exopolymer particles, TEP, from dissolved precursor material. Mar Ecol Prog Ser 192:1-11

* Passow U, Shipe R, Murray A, Pak D, Brzezinski M, Alldredge A (2001) The origin of transparent exopolymer particles (TEP) and their role in the sedimentation of particulate matter. Cont Shelf Res 21:327-346

* Paul C, Pohnert G (2011) Interactions of the algicidal bacterium Kordia algicida with diatoms: regulated protease excretion for specific algal lysis. PLOS ONE 6:e21032

* Paul C, Mausz MA, Pohnert G (2013) A co-culturing/ metabolomics approach to investigate chemically mediated interactions of planktonic organisms reveals influence of bacteria on diatom metabolism. Metabolomics 9: 349-359

* Perkins D, Pappin D, Creasy D, Cottrell J (1999) Probabilitybased protein identification by searching sequence databases using mass spectrometry data. Electrophoresis 20: 3551-3567

Ribardo DA, Hendrixson DR (2011) Analysis of the LIV system of Campylobacter jejuni reveals alternative roles for LivJ and LivK in commensalism beyond branched-chain amino acid transport. J Bacteriol 193:6233-6243

Robinson WG, Coon MJ (1957) The purification and properties of $\beta$-hydroxyisobutyric dehydrogenase. J Biol Chem 225:511-521

Rooney-Varga J, Giewat M, Savin M, Sood S, LeGresley M, Martin J (2005) Links between phytoplankton and bacterial community dynamics in a coastal marine environment. Microb Ecol 49:163-175

* Seymour JR, Ahmed T, Marcos, Stocker R (2008) A microfluidic chemotaxis assay to study microbial behavior in diffusing nutrient patches. Limnol Oceanogr Methods 6: $477-488$

* Seymour JR, Ahmed T, Stocker R (2009) Bacterial chemotaxis towards the extracellular products of the toxic phytoplankton Heterosigma akashiwo. J Plankton Res 31:1557-1561

Shevchenko A, Tomas H, Havlis J, Olsen JV, Mann M (2006) In-gel digestion for mass spectrometric characterization of proteins and proteomes. Nat Protoc 1:2856-2860

* Sison-Mangus MP, Jiang S, Tran KN, Kudela RM (2014) Host-specific adaptation governs the interaction of the marine diatom, Pseudo-nitzschia and their microbiota. ISME J 8:63-76

* Sonnenschein EC, Gärdes A, Seebah S, Torres-Monroy I, Grossart H, Ullirich MS (2011) Development of a genetic system for Marinobacter adhaerens HP15 involved in marine aggregate formation by interacting with diatom cells. J Microbiol Methods 87:176-183

Sonnenschein EC, Syit DA, Grossart H, Ullrich MS (2012) Chemotaxis of Marinobacter adhaerens and its impact on attachment to the diatom Thalassiosira weissflogii. 
Appl Environ Microbiol 78:6900-6907

Teeling H, Fuchs BM, Becher D, Klockow C and others (2012) Substrate-controlled succession of marine bacterioplankton populations induced by a phytoplankton bloom. Science 336:608-611

Vanni P, Giachetti E, Pinzauti G, McFadden BA (1990) Comparative structure, function and regulation of isocitrate lyase, an important assimilatory enzyme. Comp Biochem Physiol B Comp Biochem 95:431-458

Editorial responsibility: Ilana Berman-Frank, Ramat Gan, Israel
Wagner-Döbler I, Ballhausen B, Berger M, Brinkhoff $\mathrm{T}$ and others (2010) The complete genome sequence of the algal symbiont Dinoroseobacter shibae: a hitchhiker's guide to life in the sea. ISME J 4:61-77

Wissenbach U, Six S, Bongaerts J, Ternes D, Steinwachs S, Unden G (1995) A third periplasmic transport-system for L-arginine in Escherichia coli: molecular characterization of the artPIQMJ genes, arginine binding and transport. Mol Microbiol 17:675-686

Submitted: July 7, 2016; Accepted: October 28, 2016

Proofs received from author(s): December 5, 2016 